\title{
Students' Perspectives on the Quality of Evaluation Practices and Feedback in College of Education and College of Science in Eritrea
}

\author{
Ermias Melake Tesfay \\ Asmara College of Education, Asmara, Eritrea
}

\begin{abstract}
The aim of this study is to explore students' perspectives on the quality of evaluation practices and feedback in College of Education and College of Science. The sample population consists of 135 third-year and fourth-year students' from both Colleges. Questionnaires, using a 5-point Likert scale, were administered to all participants whilst two focus group discussions were also conducted. The findings from survey data and focus group discussions showed that the majority of students hold a positive perception on the quality of the evaluation practices but had a negative perception on methods of awarding grades and administrators' role in listening to the students' complaints about the courses. Looking into the differences among years of study and gender, the analysis from the questionnaire showed that there is no statistically significant difference between third-year and fourthyear students, in both Colleges with respect to the quality of evaluation practices and feedback. The study recommends that the Colleges in Eritrea improve the quality of fairness and feedback during course assessments. Keywords: evaluation, feedback, quality, students' perception
\end{abstract}

DOI: $10.7176 / \mathrm{JEP} / 11-19-03$

Publication date:July $31^{\text {st }} 2020$

\section{Introduction}

Evaluation practices and feedback have a long and profound history in the context of higher education. The process of evaluation is very complex and comprehensive, which includes notions like measurement, examination, and assessment within it, and it has been a persistent part of objectives, pedagogy, and content. There are different dimensions of evaluation in higher education, such as teacher evaluation, curriculum evaluation, student evaluation, program evaluation, and most prominently evaluation of the policy of higher education. For that reason, defining evaluation has proven to be difficult in higher education.

Educators and researchers have provided numerous definitions of evaluation that try to clarify what evaluation is and the several ways they are used in colleges. Russ-Eft \& Preskill (2009), for example, defined evaluation as the process of collecting, recording, interpreting, and passing judgments, using learners' progress and attainments in the development of the knowledge, values, attitudes, and skills. Scriven (1991) defined evaluation as a product of the process of determining the quality, value, or significance. Another one by Tyler (1950) defined evaluation as the process of determining and realizing the educational objectives. Bennett (2011) also defines evaluation as a process of judging the students' achievements of knowledge, skills, and values using certain appraisal. Mondal and Mete (2014), on their part have defined it as the systematic gathering and interpretation of students' attainments, which is leading to the process of decision making.

In the same vein, Rossi, Lipsey, \& Henry (2018) have also defined evaluation as the collection, analysis, and interpretation of information about any aspect of a program of education, as part of a recognized process of judging its effectiveness, its efficiency and any other outcomes it may have. Furthermore, Brown, Getz, Pettersson, \& Wallstam (2015) defined evaluation as the systematic acquisition and assessment of information to provide useful feedback about some object.

Although evaluation has been defined by different researchers in different ways, the majority of researchers agree that students' evaluation is an essential element and comprises complex processes in higher education, and the results have a significant effect on students' livelihood. Thus, the activity of the evaluation process should be reliable, valid, intentional, and always done professionally. Lecturers have a pivotal role in making the students aware of the evaluation approach being used for their course, the different evaluation methods that they use, the expectation required to fulfill, and what standards and principles will be applied for their evaluation performance.

\section{The Context for the Study}

As a researcher, it is imperative to offer readers about the context of the study as well as the background of the Colleges and departments they have. Currently, there are six Colleges in Eritrea namely, Asmara College of Education, College of Engineering and Technology, College of Science, College of Business and Social Sciences, Orotta College of Medicine and Health Science, and Hamelmalo Agricultural College. The study was carried out in the former College of Education (renamed as Asmara College of Education after the 2018 higher education restructuring) and College of Science in November 2018. 
College of Education was established as a unit in the 1993/94 academic year at the then University of Asmara (UoA). Then it advanced/upgraded into a faculty in 1997. In 2003 the faculty was established as College of Education and was relocated to Eritrea Institute of Technology (EIT). Currently, as of 2018, the college is relocated back to Asmara and made some changes in the structure and organization of the courses and programs.

Over the years, the College of Education has been offering many courses in line with the College of Science in Eritrea Institutes of Technology. However, as per the directive of the National Higher Education and Research Institutions (NHERI), which was undertaken at the beginning of the 2018/19 academic year, the College of Education was moved from Eritrea Institute of Technology Mainefhi to the capital Asmara, and officially named as Asmara College of Education. Asmara College of Education has four departments, namely: Department of Educational Psychology and Administration, Department of Social Science Education, Department of Natural Science Education, and Department of English Language Teaching.

College of Science is located in Mai Nefhi, Zoba Maekel, $20 \mathrm{Km}$ - North West of Asmara. The college consists of different departments such as Biology, Chemistry, Mathematics, Physics, Geology, Library Information Science, and Statistics. The bachelor degree programs are 4-year programs, and the College also has five different master's degree programs in Biology, Chemistry, Mathematics, Physics, and Statistics.

\section{Purpose of the Study}

In recent years, researchers, educators, stakeholders, and policymakers throughout the world have questioned the current evaluation practices employed in higher education. Many educators argue that due to the increasing number of students entering universities and colleges and their diversity; still, the current evaluation practices focus too much on measuring students' capability to memorize knowledge using objective questions at the expense of problem-solving and skills. This shows that the current evaluation practice is rife with assessments that measure knowledge of core content areas rather than on $21^{\text {st }}$-century evaluation practices and feedback.

Besides, educators raised a lot of concerns about the quality and quantity of student feedback and the inconsistency across departments and within colleges (Higgins, Hartley, \& Skelton, 2002). Therefore, the purpose of this research was to gather data in order to understand students' perceptions of the quality of evaluation practice and feedback in the College of Education and College Science in Eritrea. The primary goal of this is to use the data to both improve the quality evaluation practice and feedback, and to plan for the future using a continuous cycle of improvement.

\section{Literature Review}

It is understood that evaluation practices in higher education are complex which involves many issues. This is evident in the literature on student evaluation practice and feedback is frequently contentious. Numerous papers and documents put forward strong philosophical arguments for the need to discover the evaluation practice in more detail than it has been before. This is partly due to the significant changes in the mode of delivery, introduction of different modular learning, increase in number and diversity of students over the last twenty years (Stuart, Solomon, \& Akroyd, 2006).

According to Astin (2012), evaluation plays a very significant role in higher education, and there are mainly four reasons why we evaluate students, first is to compare students attainments with each other students, second to check if students meet a particular standard, third to support the student's learning, and finally to check whether the teaching program is doing what it intends to do. While Allen, Ort, \& Schmidt (2009) stated that students benefit from evaluations in multiple ways such as smooth communication, administrator-teacher-student involvement, and step-by-step instructions.

Moreover, when teachers use continuous assessment supplemented with appropriate feedback, the whole classes have the potential to benefit (Heritage, 2010). Feedback is fundamental to the student's attainment of knowledge and can encourage and inspire students through initial transition and also throughout their study. According to Murphy and Cornell (2010), feedback is considered as the essential and final point in the concept of evaluation in which it tells the advantages and limitations of the students or the system. Moreover, research studies have found that feedback has the most influential effect on students' attainment, progression, and retention (Bloxham \& Boyd, 2007; Yorke, 2003).

According to Fatima (2010), the scope and complexity of the evaluation practices that are carried out in any college will vary according to the nature of the college, as certainly, will the evaluation styles used. Whatever the situations, still, the significance of using evaluation practices to monitor the instructional system should shed light on the objectives, appropriateness of the teaching styles used, the content adopted, the techniques of implementation, and the assessment techniques. With each sequential cycle of the evaluation, the teaching-learning processes should become gradually tuned and should accordingly become more effective and efficient through a continuous process of evaluation practices and feedback.

An evaluation can be formative or summative. Formative evaluation is a type of evaluation that takes place during the process of teaching and learning, and its primary function is to help, deliver, guide, and monitor the 
teaching-learning process by providing continuous feedback.

The essence of formative evaluation is well captured by Yorke (2003); in which he mentioned that formative evaluation is carried out for three different reasons. First, to give acknowledgement for what has been achieved to the anticipated standard, second to correct the incorrect and the third is to encourage emancipation by informing the learners to opportunities which he or she may not have previously discerned. Furthermore, Alonge (2004) and Kolawole (2010), stated that continuous assessments combined with appropriate and suitable written feedback help to remove the learning weaknesses and provide strengths towards summative evaluation.

Summative evaluation is conducted at the end of the course or program, and its function is to find out the extent to which the instructional objectives have been achieved or not. According to Patton (2002), the primary purpose of summative evaluation is to examine the overall competence and effectiveness of the program, the contents, and the product, in order to decide on its sustainability and further inferences.

\section{Methods}

This study employed a mixed-method design. The choice for the mixed-method design was made because it combines qualitative and quantitative data into a coherent and harmonious combination in order to enrich results. Moreover, using the mixed method in a single research study allows finding data intersections between the two collection methods and understanding of the research question than either a quantitative or qualitative approach on its own would provide (Cohen, Manion, \& Morrison, 2018).

The researcher selected College of Education and College of Science as a research site from the six available Colleges in Eritrea. The researcher employed stratified random sampling for both quantitative and qualitative methods. One hundred thirty five students from the two Colleges, 57 students from the College of Education, and 78 students from College of Science were selected. The sample consisted of 70 male and 65 female students. The researcher also conducted two focus group discussions involving six to eight students from third-year and fourthyear students of the two Colleges.

The target population for this study were third-year and fourth-year students of the College of Education and College of Science in Eritrea. The researcher felt that by the time students reach third-year and fourth-year they would have enough experience and knowledge to provide significant and more accurate feedback with respect to quality of evaluation practices and feedback.

Before the administration of the questionnaire, to ensure validity and reliability, it was reviewed by the experts and conducted a reliability analysis. The reliability analysis showed the reliability of the two constructs, which were 0.77 cronbach's alpha for both constructs. Since both reliabilities were greater than 0.70 , the instrument was considered to produce reliable scores. With regards to validity, the validity of the questionnaire was assured by the expert who has developed it. However, lecturers in Eritrea also gave their input, and finally, the questionnaire was revised and improved in the light of opinions of the lecturers and experts so that ambiguous and poorly prepared items were modified.

The data was collected from November 2018 to January 2019, following a pilot test in October 2018 in College of Education involving 20 students. The measurement of items in the survey questionnaires was based on 5 five-point Likert scale (5-Strongly Agree, 4-Agree, 3-Somewhat Agree, 2-Disagree, 1-Strongly Disagree), where higher responses indicated higher levels of agreement. In the analysis, however, the five-point Likert Scale was then re-coded to three scales with 1 denoting "Low Agreement", 2 "Moderate Agreement" and 3 "High Agreement" to give more distinct focus for the interpretation of students' perceptions of the quality of evaluation practice and feedback. The quantitative data were analyzed using SPSS, for statistical analysis. And the recorded focus group discussions, each approximately 50 minutes in length were analyzed using top-down thematic analysis, whereby the original data were transcribed, coded, and interpreted thematically.

\section{Findings}

\subsection{Demographic Characteristics of Respondents}

Table 1 indicates that, from the total participants of 135 students, 57 (42.2\%) of the respondents were from the College of Education and 78 (57.8\%) from College of Science. In relation to the year of the study, $49.6 \%$ were third-year students, while the remaining $50.4 \%$ fourth-year students. In terms of gender, $51.9 \%$ male and $48.1 \%$ were female students. 
Table 1: Demographic Characteristics of Respondents

\begin{tabular}{lllll}
\hline & Characteristic & Sample size & Frequency & Percent \\
\hline Colleges & College of Education & 135 & 57 & 42.2 \\
& College of Science & & 78 & 57.8 \\
Program & Degree & 135 & 100 & 100 \\
Year & Third-year & 135 & 67 & 49.6 \\
& Fourth-year & & 68 & 50.4 \\
& Male & 135 & 70 & 51.9 \\
& Female & & 65 & 48.1 \\
\cline { 2 - 5 } & & &
\end{tabular}

6.2 Students' perspectives on the Quality of Evaluation Practice in College of Education and College of Science in Eritrea

The data on evaluation practice is displayed in Table 2. It has a total of seven statements, which include the provision of adequate time for exam preparation, varied forms of evaluation, proper exam invigilation, freedom of choice in selecting group members, exam coverage, suitability to the level of students, and clearness of exam questions.

Table 2: Descriptive results of Students' perceptions on the quality of evaluation practice in College of Education and College of Science in Eritrea

\begin{tabular}{|c|c|c|c|c|c|c|c|c|c|}
\hline \multirow{3}{*}{$\begin{array}{l}\text { Quality attribute } \\
\text { Evaluation practice }\end{array}$} & \multirow{3}{*}{$\mathrm{N}$} & \multicolumn{6}{|c|}{ Level of Agreement } & \multirow[b]{3}{*}{ Mean } & \multirow[b]{3}{*}{$S D$} \\
\hline & & \multicolumn{2}{|c|}{ Low } & \multicolumn{2}{|c|}{ Mod } & \multicolumn{2}{|c|}{ High } & & \\
\hline & & $(f)$ & $\%$ & (f) & $\%$ & $(f)$ & $\%$ & & \\
\hline $\begin{array}{l}\text { 1. Students are given time to prepare } \\
\text { adequately for the examinations. }\end{array}$ & 135 & 23 & 17.0 & 26 & 19.3 & 86 & 63.7 & 2.47 & 0.771 \\
\hline $\begin{array}{l}\text { 2. Lecturers use oral, written and other } \\
\text { forms of evaluation to assess students' } \\
\text { progress. }\end{array}$ & 135 & 31 & 23.0 & 47 & 34.8 & 57 & 42.2 & 2.19 & 0.787 \\
\hline 3. The examinations are well invigilated. & 135 & 20 & 14.9 & 55 & 40.7 & 60 & 44.4 & 2.30 & 0.713 \\
\hline $\begin{array}{l}\text { 4. Lecturers give freedom to students to } \\
\text { choose their own group members when } \\
\text { assigned group }\end{array}$ & 135 & 23 & 17.1 & 40 & 29.6 & 72 & 53.3 & 2.36 & 0.759 \\
\hline $\begin{array}{l}\text { 5. Lecturers prepare examination questions } \\
\text { that cover the important aspects of the } \\
\text { course. }\end{array}$ & 135 & 18 & 13.3 & 34 & 25.2 & 83 & 61.5 & 2.48 & 0.721 \\
\hline $\begin{array}{l}\text { 6. Lectures give assessment tests suitable to } \\
\text { the level of students }\end{array}$ & 135 & 24 & 17.8 & 53 & 39.2 & 58 & 43.0 & 2.25 & 0.740 \\
\hline \multirow[t]{2}{*}{$\begin{array}{l}\text { 7. Lecturers' examination questions are } \\
\text { clear and fair. }\end{array}$} & 135 & 31 & 23.0 & 48 & 35.5 & 56 & 41.5 & 2.19 & 0.784 \\
\hline & & \multicolumn{5}{|c|}{ Overall Mean Score } & & 2.32 & \\
\hline
\end{tabular}

Key: $\mathrm{N}=$ Number of participants, Low = Lower Agreement; Mod = Moderate Agreement; High = Higher Agreement; $\mathrm{SD}=$ Standard Deviation

As stated in Table 2, the respondents agreed with all the statements of the quality of evaluation practice to some extent. They had a higher agreement on 'the provision of adequate time for exam preparation' $(\mathrm{M}=2.47$, $\mathrm{SD}=0.77)$; 'examination questions cover the important aspects of the course' $(\mathrm{M}=2.48, \mathrm{SD}=0.72)$; 'students freedom of choice in selecting group members' $(\mathrm{M}=2.36, \mathrm{SD}=0.75)$; 'proper exam invigilation' $(\mathrm{M}=2.30$, $\mathrm{SD}=0.71)$; and 'appropriateness of assessment tests to the level of students' $(\mathrm{M}=2.25, \mathrm{SD}=0.74)$. Respondents also agreed to some extent on lecturers ability to use varied forms of assessment $(M=2.19, S D=0.78)$ and clearness of exam questions $(\mathrm{M}=2.19, \mathrm{SD}=0.78)$. This implies that students had high perceptions for the provision of adequate time for exam preparation and exam coverage but less positive perception of the suitability of the evaluation practices and clearness of exam questions. The overall mean score of evaluation practice is 2.32 , which suggests a positive perception of students on lecturer evaluation practice.

The information gathered from the focus group discussions of the two Colleges generally indicates that students hold positive perceptions on the evaluation practice. Students pronounced that their lecturers provide adequate time to make preparation for the exam, proper exam invigilation, and the use of continuous assessment.

The focus group noted the issue as follows: lecturers provide us sufficient time to prepare for the mid and final exams. Also, students revealed that their lecturers are strict during invigilation, such as on starting the exam on time, reshuffling the sitting arrangement, and providing accurate instructions.

Furthermore, the students also described that their lecturers sometimes employ formative assessment techniques. They noted as follows: 
A student from the College of Education mentioned that their lecturers utilize continuous assessment techniques, such as project, group work activity, assignments, presentations, quizzes, and exams. However, a student from College of Science revealed some of their lecturers don't use continuous assessment, "we don't deny the fact that some of our lecturers provide us lab works, assignments, and projects, though some of the lecturers don't assess us formatively and as being claimed by our instructors the reason for them to do so is due to shortage of time, workload, and large class size."

According to the information gathered from both sets of data, a positive student perception of lecturers' evaluation practice can be recognized.

\subsection{Students' perspectives on Fairness and Feedback of Lecturer in College of Education and College Science in Eritrea}

The construct on the quality of fairness and feedback consists of six statements that involve administration's role in the handling of student's opinions, marking and timely feedback, method of grading, fairness on grading students, setting standards and due dates for assessments, and fairness in grading.

Table 3: Descriptive results of students' perceptions on fairness and feedback of lecturer in College of Education and College of Science in Eritrea

\begin{tabular}{|c|c|c|c|c|c|c|c|c|c|c|}
\hline \multirow[t]{2}{*}{$\mathrm{S} / \mathrm{n}$} & \multirow{2}{*}{$\begin{array}{l}\text { Quality attribute } \\
\text { Fairness and Feedback }\end{array}$} & \multirow[b]{2}{*}{$\mathrm{N}$} & \multicolumn{6}{|c|}{ Level of Agreement } & \multirow[b]{2}{*}{ Mean } & \multirow[b]{2}{*}{$S D$} \\
\hline & & & $\begin{array}{l}\text { Low } \\
(f)\end{array}$ & $\%$ & $\begin{array}{l}\operatorname{Mod} \\
(f)\end{array}$ & $\%$ & $\begin{array}{l}\text { High } \\
(f)\end{array}$ & $\%$ & & \\
\hline 8 & $\begin{array}{l}\text { The administration takes students' opinion } \\
\text { about the course seriously. }\end{array}$ & 135 & 64 & 47.4 & 40 & 29.6 & 31 & 23.0 & 1.76 & 0.805 \\
\hline 9 & $\begin{array}{l}\text { Lecturers mark examinations on time and } \\
\text { give students feedback immediately. }\end{array}$ & 135 & 27 & 20.0 & 45 & 33.3 & 63 & 46.7 & 2.27 & 0.775 \\
\hline 10 & $\begin{array}{l}\text { Lecturers' method of giving grades is } \\
\text { consistent and clearly understood. }\end{array}$ & 135 & 60 & 44.4 & 43 & 31.9 & 32 & 23.7 & 1.79 & 0.802 \\
\hline 11 & Lecturers are fair in grading students. & 135 & 35 & 25.9 & 58 & 43.0 & 42 & 31.1 & 2.05 & 0.756 \\
\hline 12 & $\begin{array}{l}\text { Lecturers set standards and due dates for } \\
\text { assessment tests that are clear, fair and } \\
\text { reasonable. }\end{array}$ & 135 & 21 & 15.6 & 61 & 45.1 & 53 & 39.3 & 2.24 & 0.704 \\
\hline 13 & $\begin{array}{l}\text { Lecturers treat all students fairly and in an } \\
\text { equitable manner during assessment. }\end{array}$ & 135 & 26 & 19.3 & 51 & 37.7 & 58 & 43.0 & 2.24 & 0.755 \\
\hline
\end{tabular}

Overall Mean Score

Key: $\mathrm{N}=$ Number of participants, Low= Lower Agreement; Mod = Moderate Agreement; High $=$ Higher Agreement; $\mathrm{SD}=$ Standard Deviation

In terms of fairness and feedback, data in Table 3 reveals that respondents agree with some of the statements regarding fairness and feedback. For instance, students agreed that lecturers mark examinations on time and give students feedback immediately $(\mathrm{M}=2.27, \mathrm{SD}=0.77)$, treat all students fairly and in an equitable manner during assessment $(\mathrm{M}=2.24, \mathrm{SD}=0.75)$, and set standards and due dates for assessment tests $(\mathrm{M}=2.24, \mathrm{SD}=0.70)$.

To some extent, respondents also agreed on 'lecturers' fairness in grading students' $(\mathrm{M}=2.05, \mathrm{SD}=0.75)$. However, a significant proportion of students (47.4\%) had a lower agreement as compared to moderate $(29.6 \%)$ and higher $(23.0 \%)$ on the role of administrative staff on listening to students' opinions about the course $(\mathrm{M}=1.76$, $\mathrm{SD}=0.80)$. Students also had a lower agreement on lecturers' method of grading $(\mathrm{M}=1.79, \mathrm{SD}=0.802)$. The findings suggest that students had moderate perceptions of the timely feedback to the students and due dates for assessment but negative perception of the role of administrative staff in handling student's opinions and methods of awarding grades. The overall mean score of 2.06 implies a moderate perception of the quality of fairness and feedback.

These perceptions are equally consistent with the data gathered during focus group discussions. The students expressed that even though lecturers mark examinations on time, they still had concerns regarding methods of awarding grades and administrators' role in listening to the students complain about the course.

A student from College of Education quoted saying:

Lecturers give broad and general feedback, but they don't have time to provide feedback to every learner in the class, and another student stated his dissatisfaction with the quality and format of feedback and further noted that he needs feedback to improve and allow him to move forward regardless of his mark. Another student from College of Science criticized the methods of awarding grades and administrators' roles. The student lamented:

The lecturer's standard of awarding grades is not clear. Sometimes we receive unexpected grades, though we are quite sure performed well in the exams, and this makes us fail unfairly. Another student mentioned his discontentment on the roles of administration staff in listening to students concerning their courses. 
Generally, from both sets of data, less positive student perception of lecturers' fairness and feedback can be recognized.

Differences between the quality of evaluation practice and feedback was also conducted. Tables 4-6 depict the data on students' perspectives of the quality of evaluation practice and feedback and their college, year of study, and gender variables. An independent sample t-test conducted on mean scores of colleges, year level, gender variables of the respondents, as shown in Tables 4-6. The test involved Levene' test for Equality of Variance (EV). In Tables 4-6 below the equality variances were assumed, because the p-value (significance level) in Levene's Test is greater than the critical p-value of 0.05 . The confidence interval of the difference is at $95 \%$.

Table 4: t-test between College and quality of evaluation practices \& feedback

\begin{tabular}{llllllll}
\hline & & \multicolumn{2}{l}{$\begin{array}{l}\text { Levene's } \\
\text { Equality of Variances }\end{array}$} & \multicolumn{2}{c}{ Test for } & t-test for Equality of Means \\
\cline { 3 - 8 } $\mathrm{S} / \mathrm{N}$ & Constructs & $\mathrm{F}$ & Sig. & $\mathrm{t}$ & $\mathrm{df}$ & Sig. (2-tailed) \\
\hline \multicolumn{2}{c}{ Evaluation practice \& Feedback } & .008 & .930 & .801 & 133 & .425 \\
\hline
\end{tabular}

Table 5: t-test between year level and quality of evaluation practices \& feedback

\begin{tabular}{lllllll}
\hline & & \multicolumn{2}{l}{$\begin{array}{l}\text { Levene's } \\
\text { Equality of Variances }\end{array}$} & \multicolumn{2}{c}{ Test for } & t-test for Equality of Means \\
\cline { 3 - 7 } $\mathrm{S} / \mathrm{N}$ & Constructs & $\mathrm{F}$ & Sig. & $\mathrm{t}$ & $\mathrm{df}$ & Sig. (2-tailed) \\
\hline \multicolumn{2}{c}{ Evaluation practice \& Feedback } & .008 & .928 & .328 & 133 & .744 \\
\hline
\end{tabular}

Table 6: t-test between gender and quality of evaluation practices \& feedback

\begin{tabular}{lllllll}
\hline & & \multicolumn{2}{l}{$\begin{array}{l}\text { Levene's } \\
\text { Equality of Variances }\end{array}$} & \multicolumn{2}{l}{ Test for } & \multicolumn{2}{l}{ t-test for Equality of Means } \\
\cline { 3 - 7 } $\mathrm{S} / \mathrm{N}$ & Constructs & $\mathrm{F}$ & Sig. & $\mathrm{t}$ & $\mathrm{df}$ & Sig. (2-tailed) \\
\hline & Evaluation practice \& Feedback & 1.050 & .307 & 1.200 & 133 & .232 \\
\hline
\end{tabular}

The t-test results on Tables 4-6 showed that there is no significant difference in students perspectives on quality of evaluation practice and feedback with variables of College of Education and College of Science (df (133) $=0.801, \mathrm{p}=0.425$ two-tailed $)$; third and fourth year $(\mathrm{df}(133)=0.328, \mathrm{p}=0.744$ two-tailed $)$; and male and female $(\mathrm{df}(133)=1.200, \mathrm{p}=0.232$ two-tailed $)$. Therefore, as it is greater than 0.05 , which indicates that there is no statistically significant difference in the mean score of the College of Education and College of Science, third-year and fourth-year students, and male and female students.

\section{Discussions of findings}

The results obtained from the questionnaire and focus group discussions were found to be in agreement with respect to students' higher agreement, moderate agreement, and lower agreement of the evaluation practices and feedback in both colleges. The survey results indicated that students had a higher agreement on the provision of time for exam preparation, exam coverage of the important aspects of the course, and students' freedom to choose their own group, which concurs with what students reported during the focus group discussions. This result has equally echoed the findings of Belanger (2016), that allowing students to form their groups contribute to positive student attitudes toward self, academic ability, and colleagues. It also permits students to have greater contact, trust, acceptance, and support among students of different races, social classes, achievement levels, and sexes. In addition, providing students ample time to prepare for examination reduces students' anxiety and enhances their achievement (Ayres, 1996).

Evaluation practices are helpful in monitoring the learning progress of students and making decisions about how to improve teaching (Tomlinson, Brimijoin, \& Narvaez, 2008). Usually, assessment data collected continuously throughout the course implementation, and that helps instructors to identify students' strengths and weaknesses and, based on that, to prepare additional or revised instruction for those who have not performed well (Yell, Busch, \& Rogers, 2007). Based on questionnaire data and focus group discussions, it was found that some of the instructors use continuous assessment in most of the courses throughout the program.

The role of administrative staff in encouraging, stimulating, and guidance had a significant influence on students learning and specifically in students' performance (Kandinko \& Mawer, 2013). Nevertheless, in this study, the administration's role in taking students' opinion about the course is low, which needs serious attention.

Marking and awarding grades is subject to scrutiny and debate, there remains extensive mystery surrounding the marking activity by lecturers (Yorke, Bridges, \& Woolf, 2000), in this study, both data showed that low students' perception on lecturers method of awarding grades. Usually, quality assurance agencies recommend institutions to have transparent and fair mechanisms for marking and moderation (Kandinko \& Mawer, 2013).

To solve these problems, lecturers need to transform conceptions of evaluation practice beyond a measuring and labeling tool towards diagnosing learning needs and continuously update themselves in changes in the 
assessment practice of their course. Besides prompt feedback, particularly for final exams and greater transparency in student grading. Furthermore, administrative staff and department heads have to be in a position to pay attention to the opinions of students regarding their courses.

\section{Conclusion and recommendations}

This study was carried out to explore the students' perspectives on the quality evaluation practice and feedback in College of Education and College of Science in Eritrea. The findings indicate that students in both Colleges had moderate perceptions of the quality of evaluation practice and feedback. The study found that lecturers give students enough time to make preparation for exams and also lecturers properly invigilate exams. In addition, students perceive that some lecturers utilize formative assessment techniques. Moreover, students have a negative perception of the role of administrative staff in handling student's opinions about the course, fairness in grading, and methods of awarding grades. Lastly, the study found that there are no significant differences in the perception between College of Education and College of Science students, third-year and fourth-year students, male and female students in relation to the quality of evaluation practice and feedback.

The study recommends for the introduction of wide-ranging and continuous assessment schemes and staff development plans so that instructors can improve the marking system, transparency in grade awarding and communication of feedback by creating different forums.

\section{References}

Allen, D., Ort, S. W., \& Schmidt, J. (2009). Supporting classroom assessment practice: Lessons from a small high school. Theory into Practice, 48, 72-80.

Alonge, M. F. (2004). Measurement and Evaluation in Education and Psychology. Ado-Ekiti: Adebayo Printing Nig. Ltd.

Astin, A. W. (2012). The philosophy and practice of assessment and evaluation in higher education. Rowman \& Littlefield Publishers.

Ayres, J. (1996). Speech preparation processes and speech apprehension. Communication Education, 45(3), 228235.

Belanger, J. R. (2016). Learning in the Laboratory : How Group Assignments Affect Motivation and Performance. Journal of Education and Learning, 5(1), 210-217. https://doi.org/10.5539/jel.v5n1p210

Bennett, R. E. (2011). Formative assessment: A critical review. Assessment in Education: Principles, Policy \& Practice, 18(1), 5-25.

Bloxham, S., \& Boyd, P. (2007). Developing Effective Assessment in Higher Education. Maidenhead: Open University Press.

Brown, S., Getz, D., Pettersson, R., \& Wallstam, M. (2015). Event evaluation: definitions, concepts and a state of the art review. International Journal of Event and Festival Management, 6(2), 135-157.

Cohen, L., Manion, L., \& Morrison, K. (2018). Research Methods in Education (8th ed). London \& New York: Routledge.

Creswell, J. W., \& Plano Clark, V. L. (2011). Designing and Conducting Mixed Methods Research (2nd ed). Thousand Oaks, CA: Sage.

Fatima, J. (2010). A study on evaluation of post-graduate programmes of teacher education in Pakistan (unpublished PhD Dissertation). Arid Agriculture University, Rawalpindi.

Gulliksen, A.-K., \& Audensen, E. (2013). Report on recognition of higher education in Eritrea and Ethiopia.

Heritage, M. (2010). Formative assessment and next-generation assessment systems: Are we losing and opportunity? Paper presented at the meeting of the Council of Chief State School Officers, Washington, DC.

Higgins, R., Hartley, P., \& Skelton, A. (2002). The conscientious consumer: reconsidering the role of assessment feedback in student learning. Studies in Higher Education, 27(1), 53-64.

Kandinko, C. B., \& Mawer, M. (2013). Student expectations and perceptions of higher education. A study of UK higher education commissioned by the quality assurance agency.

Kolawole, E. B. (2010). Principles of test construction and administration (Revised Edition). Lagos: Bolabay Publications.

Mondal, A., \& Mete, J. (2014). Continuous and Comprehensive Evaluation-An Appraisal.

Murphy, C., \& Cornell, J. (2010). Student perceptions of Feedback: seeking a coherent fl ow. Practitioner Research in Higher Education, 4(1), 41-51.

Patton, M. Q. (2002). Qualitative Research \& Evaluation Methods (3rd Ed). Thousand Oaks; London; New Delhi: SAGE Publications.

Rossi, P. H., Lipsey, M. W., \& Henry, G. T. (2018). Evaluation: A systematic approach. Sage publications.

Russ-Eft, D., \& Preskill, H. (2009). Evaluation in organizations: A systematic approach to enhancing learning, performance, and change. Basic Books.

Scriven, M. (1991). Evaluation thesaurus (Fourth edi). Newbury Park : Sage. 
Stuart, M., Solomon, L., \& Akroyd, K. (2006). Student Assessment and Feedback Research.

Tomlinson, C. A., Brimijoin, K., \& Narvaez, L. (2008). The differentiated school: Making revolutionary changes in teaching and learning. ASCD.

Tyler, R. W. (1950). Basic principles of curriculum and instruction. Chicago: University of Chicago Press.

Yell, M. L., Busch, T. W., \& Rogers, D. C. (2007). Providing instruction and monitoring student performance. Beyond Behavior, 17(1), 31-38.

Yorke, Bridges, \& Woolf. (2000). Mark distributions and marking practices in UK higher education: some challenging issues. Active Learning in Higher Education, 1(1), 7-27.

Yorke, M. (2003a). Formative assessment in higher education: moves towards theory and the enhancement of pedagogic practice. Higher Education, 45(4), 471-501.

Yorke, M. (2003b). Formative assessment in higher education: Moves towards theory and the enhancement of pedagogic practice. Higher Education, 45(4), 477-501. 